\title{
Constructivism Experiences in Teaching-Learning Transaction among Adventist Secondary Schools in South Nyanza, Tanzania
}

\author{
Baraka Manjale Ngussa ${ }^{1}$, Lazarus Ndiku Makewa ${ }^{2, *}$ \\ ${ }^{1}$ Ag. Extension Director, University of Arusha- Musoma Centre, Tanzania \\ ${ }^{2}$ Dean, School of Education, University of Eastern Africa, Baraton, Kenya \\ *Corresponding author: ndikul@gmail.com
}

Received September 23, 2014; Revised October 09, 2014; Accepted December 08, 2014

\begin{abstract}
This study sought to investigate experiences of constructivism principles in teaching-learning transaction among Adventist Secondary Schools in South Nyanza, Tanzania. A sample of 65 students was randomly selected to fill the questionnaire. T-test, ANOVA and Pearson-product moment correlation coefficient analyzed null hypotheses. Students established that their established their teachers always employ constructivism principles and that student academic performance is influenced by teaching modalities, active participation and classroom setup. High performing students tend to engage in active participation more frequently than their lower performing counterparts. Classroom setups influence performance of students, modalities of teaching and the rate of students' active participation. It is therefore recommended that classroom sessions should be dominated by activities that lead learners to actively seek solutions to existing problems and discover new information through a varied range of guided activities. School administrations are called upon to ensure that classrooms have sufficient space; teachers are also encouraged to make sure that seating arrangements are well organized to allow students-teacher and studentstudent interaction. Further study can be conducted on teachers' demographic characteristics and application of constructivism theory in teaching-learning transaction.
\end{abstract}

Keywords: Constructivism, teaching-learning transaction, interaction, Adventist, Secondary Schools, Tanzania

Cite This Article: Baraka Manjale Ngussa, and Lazarus Ndiku Makewa, "Constructivism Experiences in Teaching-Learning Transaction among Adventist Secondary Schools in South Nyanza, Tanzania." American Journal of Educational Research, vol. 2, no. 11A (2014): 1-7. doi: 10.12691/education-2-11A-1.

\section{Introduction}

While there are many theories and schools of thought from which principles of effective learning can be derived, constructivism theory is of paramount importance. This is supported by the most recent study of Odagboyi, Sambo, Musa Onche (2014) who contend that knowledge is not just handed down to the learner from the teacher, but it should be actively constructed by the learner. A wide range of educators, instructional technologists, educational psychologists and curricularists ((e.g. Gagne, Wager, Golas, \& Keller, (2005; Massouleh and Jooneghani 2012; Moore, 2009; Ornstein \& Hunkins 2009; Reigeluth, 1999; Reiser \& Dempsey, 2007; Savage, 1999; Schunk, 2004; Tuckman \& Munetti, 2011) agree with this assertion by regarding constructivism as important determinant from which effective teaching and learning can be implemented. These writers advocate for student-centered instruction which has some connections with constructivism theory of learning, with great emphasis on maximization of student's activity and practice and minimization of teacher's domination in the teaching-learning transaction.

In a simple term, constructivism can be defined as learners' active creation of their own knowledge by trying to make sense out of material that is presented to them by the teachers (Reigeluth, 1999). According to Ornstein and Hunkins (2009), constructivism keeps individual learners actively involved in the process of thinking and learning. Reiser et al (2007) regard constructivism as a belief that reality is constructed by individuals and social groups based on their experiences with and interpretation of the world. Moore (2009) describes constructivism as an approach of teaching and learning whereby students construct their unique mental image by combining information in their heads with the information they receive through their sense organs. In this approach, teacher centered strategies of learning such as lecture methods are minimized and multiple ways of receiving information are honored.

Savage (1999) describes constructivism as a system of learning, whereby students create their own knowledge through active interaction with the world around them. Gagne et al (2005) consider constructivism to be practical and group oriented in that constructivist designers centre instruction on realistic problems, transfer of learning and organized group works, where learners can work collaboratively to discover new concepts and solve problems. They contend that people in groups solve problems faster and better than individuals. They finally 
advise that it is the responsibility of the teacher to monitor students individually to determine if they developed problem solving skills. Smaldino, Lowther and Russel (2008) consider constructivism as an approach of teaching that engages students in meaningful, problem solving experiences and experiential learning. In this approach, learners situate learning experiences within their own experience. Learning occurs most effectively when students are directly involved in problem solving activities and measurement of learning is based on the ability for learners to solve problems and use knowledge to facilitate critical thinking in real life situations.

\subsection{Research Problem}

While constructivism can be regarded as a theory that supports construction of knowledge by the individual (Bandhana, 2010), not much has been researched on practical applicability of constructivism in teachinglearning transaction in the context of Adventist Secondary Schools in Tanzania. A few related studies such as that of Ishaq and Rani (2011) examined the rationale for the use of the discussion and constructivism methods as democratic teaching methods. A similar study by Supriyadi (2013) aimed at developing teaching material using constructivism approach to improve students' skill in writing scientific paper and to test the product effectiveness of learning process in writing scientific paper in the class. This study sought to investigate experiences of constructivism principles in teachinglearning transaction among Adventist Secondary Schools in South Nyanza, Tanzania. South Nyanza Conference is a sub administrative unit of Northern Tanzania Union Conference, comprising of Mwanza, Shinyanga, Geita and Simiyu regions. In these regions, there are three Adventist Secondary schools namely Bupandagila Secondary School, Ngulyati Secondary School and

Nyanza Secondary School.

\subsection{Research Questions}

The study intended to answer the following research questions:

1. What are the overall mean scores of students on application of constructivism theory in teaching-learning transaction?

2. Is there significant difference in teaching-learning active participation by students categorized according to class size, academic performance and frequency of engagement in group learning experiences?

3. Is there significant relationship between students' academic performance and teaching modality, active participation and classroom setup?

\section{Review of Related Literature}

In this manuscript, a wide range of literature has been consulted to throw more light on constructivism principles and their implication on teaching-learning transaction. Extended literature review has revealed that among other characteristics of constructivism, class set up, modalities of teaching and collaborative learning groups can be good indicators of the applicability of constructivism theory in the teaching-learning transaction.

\subsection{Learners' Active Participation}

Active participation is the heart of constructivism theory. Hunkins (2009) and Savage (2009) give the following characteristics that have connection to active participation in constructivism point of view:

- Students are allowed to ask questions.

- Students are allowed to analyze, interpret and predict information.

- The learner is the key player in the teaching- learning transaction.

- The learners cannot passively accept information by mimicking others' wording or conclusion.

- Students connect new learning with already existing knowledge.

- Learners actively seek solutions to problems and share ideas of what they constructed themselves.

Tuckman and Munetti (2011) regard constructivism as an approach of creativity and problem-solving whereby information is discovered through some activities of learners. They give three types of constructivism (all of which are importance for effective learning); namely exogenous constructivism, endogenous constructivism and dialectical constructivism:

In exogenous constructivism, knowledge reflects the reality of the external world which greatly influences the construction process. This implies that teachers must remove the gap between what is taking place inside the classroom and what is outside. There are many different ways of accomplishing this task. Of these, field trip activities are of paramount importance. According to Olukayode (2013), students on field trips can visit people and places that they are not normally exposed to during the school days. Endogenous type of constructivism, further, has it that new knowledge develops out of earlier knowledge. This idea supports the concept of learning from known to unknown and transfer of learning. Slavin (2011, p. 481) maintains that "new learning invariably builds on prior learning" and maintains that the success of new learning will depend on whether the necessary prior learning has already taken place, student remembrance of what was learned in the preceding sessions and readiness to apply known skills in similar problems.

Dialectical type of constructivism, on the other hand, maintains that knowledge construction comes from the interaction between learners and the environments and interaction among learners and between learners and teachers. The study of Obi and Kalu (2013) concluded that classroom interaction patterns significantly enhanced the performance and retention of students. There are various variables that learners can interact with in order for effective learning to take place. This includes, but not limited to the teacher, fellow learners, learning environment and instructional resources.

\subsection{Class set up- an Essential tool for Constructivism}

A number of studies have established that class size is a chief determinant of students' level of participation in teaching-learning transaction and effective learning. Yemi and Adeshina (2013), for instance, stipulated that the size of classes in secondary schools is to be reduced to manageable number of 30-40 students per class in order to 
Influence Effective Learning of Mathematics at Senior Secondary Schools. The study of Oluoch (2014) considered classroom layout as an important factor for students' active participation in teaching and learning activities. He also postulated that the number of contributions from each learner was linked to the classroom seating and then recommended that teachers should ensure that all learners get equal opportunities to participate actively in class and should direct questions and positive feedback to all learners in the classroom. As argued by Zanden (1980), p. 346), "reduced class size provides a more desirable learning environment for students and increases teacher's effectiveness. ... smaller class teachers have more time to spend on each pupil and students have more opportunities to participate in class discussions and ask questions.”

\subsection{Teaching Strategies}

Strategy is an essential aspect of effective teaching in which a teacher meets learners at the point of their needs regardless of variation of their backgrounds. In order for effective learning to take place, teachers need to employ strategies that evoke learners' participation in the teaching-learning transaction. According to Moyles and Hargreaves (2003) this can only be possible when a teacher employs such pedagogical strategies as imagination, creativity and sensitivity. In order to attain an ideal teaching strategy, they argue, a teacher must possess and make use of appropriate presentation skills. Smaldino, Lowther and Russel (2008) mention different strategies of teaching including presentation, demonstration, cooperative learning, gaming, simulation, problem solving, discussion and tutorial. They then suggest that instructional strategy selected by a teacher influences student learning outcome and advise that teachers need to be selective in the choices of strategy they make because they are responsible for ensuring that the approach used is effective in helping learners achieve the intended learning outcomes. Al-Rawi (2013) argues that effective teaching is measured against learning outcome. Moore (2009) advises that teacher centered strategies of learning need to be minimized.

\subsection{Group Learning}

Group learning is a good indicator of constructivism in the teaching-learning transaction. Schmuck (1977) in Zanden (1988, p. 370) argued that "students exert a strong influence on one another's cognitions, attitudes and behaviors, all of which affect academic performance.” Gillies and Ashman (2002) recognize the place of group works and recommends that setting optimal group size is important because if groups are too large, some students will be overlooked while others will dominate at the expense of others. Farrant (1999) has it that it is difficult to provide a teacher for every pupil and so it is necessary to form pupils into learning groups. He gives the following advantages of having learners divided into groups: learners get opportunity for participating actively in the lessons taught and secondly, grouping is appropriate way for practical lessons for which there is insufficient equipment for every child.

Thungu, Wandera, Gachie and Alumande (2010) consider grouping as a learner-centered approach through which learners can actively participate in the teachinglearning transaction. They outline a number of advantages of teaching students in groups including reduction of failure, stigma, especially for slower learners, appreciation of each other's strengths and weakness, allowing learners access to equipment and materials which may be in short supply, encouraging joint decision making, exploration of new ideas, promotion of mutual interaction of learners from different backgrounds and increasing positive attitudes to school.

Gagne et al (2005) contend that a great deal of instruction is done when learners assemble in groups of various sizes. The size of groups can vary ranging from two person group, small groups of three to eight members and large groups of nine or more members. He also gives a number of advantages of grouping learners including support of many instructional methods associated with active learning, involving learners as participants in the process of acquiring, analyzing and organizing information, and turning it into knowledge. Smaldino et al (2008) supports the view of organizing learners into manageable groups in the so called co-operative learning. He asserts that students have potentials and they can work together to benefit each other's learning potential.

\subsection{External and Field Trip Activities}

Field trips are organized movements of students under the guidance of teachers to visit different sites from which learners can be exposed to external world. Field trips and other activities that take place outside the classroom are powerful means through which learners can be actively involved in practical learning. According to Simkins, Cole, Tavalin and Means (2002), field trips are the best instructional resources for the information that students can gather by leaving school and going out into the community. Here, learners get exposed with museums and other organizations.

Olukayode and Tina (2013, p.37) maintain that "field trip offers an opportunity for students to get exposed to people, events and the opportunity to make connections with others. Students on field trip visit people and places that they are not normally exposed to during the school day."In these practical exposures and experiences, the rate of learning is highly maximized. Lingenfelter and Lingenfelter (2003), on the other hand, support this view as they argued that experiential learning encompasses a wide range of teaching and learning strategies, which include field trips, simulations, and games and so on. Field trip, therefore remains to be important instructional resources which maximizes the rate of student participation and therefore, good results in the teaching and learning transaction.

\section{Methodology of the Study}

This study employed both descriptive and inferential statistics. Descriptive statistics analyzed research questions one while t-test analyzed research question two, Analysis of Variance (ANOVA) analyze research question three and four and Pearson-product moment correlation coefficient analyzed research question five. Questionnaire items were in four-likert scale whereby 4 denoted Strong Agreement, 3 denoted Agreement, 2 denoted 
Disagreement, and 1 denoted Strong Disagreement. Target schools had a total population of 1100 students. Form Three and Form Four students were purposely selected to participate in the study due to long time study experience as compared to their Form One and form two counterparts. This is supported by Cohen and Manion (1992) who contends that the researcher can handpick cases to be included in his sample on the basis of his judgment in order to build up a sample that is satisfactory to his specific needs. To ensure credibility, the researchers randomly selected 65 students to fill closed-ended questionnaire.

\subsection{Validity and Reliability}

Validity of the questionnaire was obtained through personal experience of the researchers who looked at the items of the questionnaire against the objectives of the study to ensure acceptable compatibility. A Cronbach Alfa of. 860 was obtained, which signified that the questionnaire items were highly reliable.

\subsection{Data Gathering Procedures}

Before the researchers went to the field for data collection certain procedures were done. First, the researchers consulted Mara Conference authority for permission to collect data from schools under investigation. Upon a written acceptance of the request, the researchers visited the school headmasters, introduced themselves and were given permission by the headmasters to collect data from students.

\section{Results and Discussion}

In this section results of the study analysis are displayed, following one research question and four hypotheses that guided this study.

\subsection{What are the overall Mean Scores of Students on Teachers' Application of Constructivism Theory in Teaching-Learning Transaction?}

In this question, mean scores of selected constructivism theory ingredients as seen in Table 1, were rated by students within the range of 2.50-3.49, suggesting agreement of learners in schools under investigation that their teachers employed constructivism in the teachinglearning transaction. This implies that teachers use learner centered approaches which have some connections with constructivism theory of learning. Application of constructivism theory in learning is held by a wide range of educators, instructional technologists, educational psychologists and curricularists (e.g. Schunk, 2004; Reiser \& Dempsey, 2007; Reigeluth, 1999; Gagne, Wager, Golas, \& Keller, 2005; Moore, 2009; Ornstein \& Hunkins 2009; Savage, 1999; Tuckman \& Munetti, 2011; and Massouleh \& Jooneghani 2012) as important determinant from which effective teaching and learning can be yielded. The observed intensity of applicability mean scores, however, can be arranged in the following descending order: group learning activities (3.1890), classroom set up (3.1692), teaching modalities (3.0974), active participation (3.0692) and external activities (2.6242). This suggests that teachers have a room to raise the intensity of the application of selected ingredients to reach the highest level of students' strong agreement.

Table 1. Students' mean scores of constructivism ingredients

\begin{tabular}{|c|c|c|c|}
\hline & $\mathrm{N}$ & Mean & Std. Deviation \\
\hline Group learning activities & 65 & 3.1890 & .62224 \\
\hline Classroom set up & 65 & 3.1692 & .62673 \\
\hline Teaching modalities & 65 & 3.0974 & .35870 \\
\hline Active participation & 65 & 3.0692 & .35951 \\
\hline External activities & 65 & 2.6242 & .63766 \\
\hline Valid N (listwise) & 65 & & \\
\hline
\end{tabular}

Since external activities were rated to be the least applicable, teachers, in harmony with the assertions of Simkins, Cole, Tavalin and Means (2002), Olukayode and Tina (2013, p. 37) and Lingenfelter and Lingenfelter (2003) need to organize for educative field trips, make learners enjoy participating in the external activities and organize teaching-learning activities and practical sessions outside the classrooms in order to raise students' maximum involvement in external activities during teaching-learning transaction.

\subsection{There is No Significant Difference in Teaching-Learning Active Participation By Students Categorized According to Class Size}

Table 2 indicates variation of mean scores of participation in teaching-learning transaction by students categorized according to class size. Those in classes of below 40 members had higher mean score of 3.1429 than those in classes of above 40 members who had the mean score of 2.9348. This suggests a slightly more chance for learners to actively participate in teaching-learning transaction in smaller classes than in larger classes. But when we critically look at the independent sample t-test in Table 3, we find a Sig. of. 864, which is greater than the critical value, leading us to accept the null hypothesis and reject the alternative. This means that there is no significant difference in teaching-learning active participation by students categorized according to class size. This indicates that students can actively participate in teaching-learning transaction regardless of number of students in the classroom. The finding is, however, against the assertions of Oluoch (2014) and Yemi and Adeshina (2013) which concluded that active participation is highly influenced by class size of learners. This however, should not encourage over crowdedness in classrooms since the study of Zanden (1980), p. 346), on the other hand, established that "reduced class size provides a more desirable learning environment for students and increases teacher's effectiveness.”

Table 2. Group Statistics of participation by students categorized according to class size

\begin{tabular}{|c|c|c|c|c|c|}
\hline & Number of students in your class & $\mathrm{N}$ & Mean & Std. Deviation & Std. Error Mean \\
\hline \multirow{2}{*}{ Active participation } & BELOW 40 & 42 & 3.1429 & .34643 & .05346 \\
\hline & ABOVE 40 & 23 & 2.9348 & .35083 & .07315 \\
\hline
\end{tabular}


Table 3. Independent Samples Test of participation by students categorized according to class size

\begin{tabular}{|c|c|c|c|c|c|c|c|c|c|c|}
\hline \multirow{3}{*}{\multicolumn{2}{|c|}{ 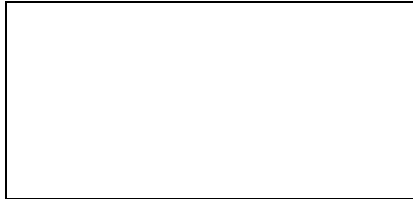 }} & \multicolumn{2}{|c|}{$\begin{array}{l}\text { Levene's Test for } \\
\text { Equality of } \\
\text { Variances } \\
\end{array}$} & \multicolumn{7}{|c|}{ t-test for Equality of Means } \\
\hline & & \multirow[t]{2}{*}{$\mathrm{F}$} & \multirow[t]{2}{*}{ Sig. } & \multirow[t]{2}{*}{$\mathrm{T}$} & \multirow[t]{2}{*}{$\mathrm{df}$} & \multirow[t]{2}{*}{$\begin{array}{l}\text { Sig. (2- } \\
\text { tailed) }\end{array}$} & \multirow[t]{2}{*}{$\begin{array}{c}\text { Mean } \\
\text { Difference }\end{array}$} & \multirow{2}{*}{$\begin{array}{c}\text { Std. Error } \\
\text { Difference }\end{array}$} & \multicolumn{2}{|c|}{$\begin{array}{l}\text { 95\% Confidence Interval } \\
\text { of the Difference }\end{array}$} \\
\hline & & & & & & & & & Lower & Upper \\
\hline \multirow{2}{*}{$\begin{array}{c}\text { Active } \\
\text { participation }\end{array}$} & $\begin{array}{c}\text { Equal } \\
\text { variances } \\
\text { assumed }\end{array}$ & .030 & .864 & 2.305 & 63 & .024 & .20807 & .09026 & .02770 & .38845 \\
\hline & $\begin{array}{c}\text { Equal } \\
\text { variances not } \\
\text { assumed }\end{array}$ & & & 2.297 & 44.899 & .026 & .20807 & .09060 & .02558 & .39057 \\
\hline
\end{tabular}

Table 4. Descriptives of level of participation by students grouped according to academic performance

\begin{tabular}{|c|c|c|c|c|c|c|c|c|}
\hline & \multirow[t]{2}{*}{$\mathrm{N}$} & \multirow[t]{2}{*}{ Mean } & \multirow{2}{*}{$\begin{array}{c}\text { Std. } \\
\text { Deviation }\end{array}$} & \multirow{2}{*}{$\begin{array}{l}\text { Std. } \\
\text { Error }\end{array}$} & \multicolumn{2}{|c|}{$\begin{array}{l}\text { 95\% Confidence Interval for } \\
\text { Mean }\end{array}$} & \multirow[t]{2}{*}{ Minimum } & \multirow[t]{2}{*}{ Maximum } \\
\hline & & & & & Lower Bound & Upper Bound & & \\
\hline $\begin{array}{l}\text { 50-100 (Good, Very Good and } \\
\text { Excellent) }\end{array}$ & 27 & 3.1914 & .39685 & .07637 & 3.0344 & 3.3483 & 2.00 & 3.67 \\
\hline 40-49 (Average) & 34 & 3.0098 & .28996 & .04973 & 2.9086 & 3.1110 & 2.50 & 3.83 \\
\hline 30-39 (Satisfactory) & 4 & 2.7500 & .39675 & .19837 & 2.1187 & 3.3813 & 2.17 & 3.00 \\
\hline Total & 65 & 3.0692 & .35951 & .04459 & 2.9801 & 3.1583 & 2.00 & 3.83 \\
\hline
\end{tabular}

Table 5. ANOVA of level of participation by students grouped according to academic performance

\begin{tabular}{|c|c|c|c|c|c|}
\hline & Sum of Squares & Df & Mean Square & $\mathrm{F}$ & Sig. \\
\hline Between Groups & .930 & 2 & .465 & 3.929 & .025 \\
\hline Within Groups & 7.341 & 62 & .118 & & \\
\hline Total & 8.272 & 64 & & & \\
\hline
\end{tabular}

Table 6. Post Hoc Tests of participation by students according to academic performance

\begin{tabular}{|c|c|c|c|c|c|c|}
\hline \multirow[b]{2}{*}{$\begin{array}{c}\text { (I) What is your performance } \\
\text { average? }\end{array}$} & \multirow[b]{2}{*}{$\begin{array}{c}\text { (J) What is your performance } \\
\text { average? }\end{array}$} & \multirow[b]{2}{*}{$\begin{array}{l}\text { Mean Difference (I- } \\
\text { J) }\end{array}$} & \multirow[b]{2}{*}{$\begin{array}{l}\text { Std. } \\
\text { Error }\end{array}$} & \multirow[b]{2}{*}{ Sig. } & \multicolumn{2}{|c|}{ 95\% Confidence Interva } \\
\hline & & & & & $\begin{array}{l}\text { Lower } \\
\text { Bound } \\
\end{array}$ & $\begin{array}{l}\text { Upper } \\
\text { Bound } \\
\end{array}$ \\
\hline \multirow{2}{*}{$\begin{array}{l}\text { 50-100 (Good, Very Good and } \\
\text { Excellent }\end{array}$} & 40-49 (Average) & $.18155^{*}$ & .08870 & .045 & .0042 & .3589 \\
\hline & 30-39 (Satisfactory) & $.44136^{*}$ & .18436 & .020 & .0728 & .8099 \\
\hline \multirow{2}{*}{ 40-49 (Average) } & $\begin{array}{l}\text { 50-100 (Good, Very Good and } \\
\text { Excellent }\end{array}$ & $-.18155^{*}$ & .08870 & .045 & -.3589 & -.0042 \\
\hline & 30-39 (Satisfactory) & .25980 & .18189 & .158 & -.1038 & .6234 \\
\hline \multirow[t]{2}{*}{ 30-39 (Satisfactory) } & $\begin{array}{c}\text { 50-100 (Good, Very Good and } \\
\text { Excellent }\end{array}$ & $-.44136^{*}$ & .18436 & .020 & -.8099 & -.0728 \\
\hline & 40-49 (Average) & -.25980 & .18189 & .158 & -.6234 & .1038 \\
\hline
\end{tabular}

4.3. There is No Significant Difference in Teaching-Learning Active Participation by Students Categorized According to Academic Performance

Table 4 indicates that the higher the academic performance, the higher the mean scores of active participation. Particularly, students with average performance of 50 and above had the mean score of 3.1914 followed by those with average of 40-49 (3.0098) and those with the average of 30-39 had the lowest mean score of 2.7500. Further, the sig of. 025 in Table 5, which is smaller than the critical value, leads us to reject the null hypothesis and accept the alternative which states that there is a significant difference in the level of active participation by students categorized according to academic performance. High performing students are the ones that engage more frequently in active participation during the teaching-learning transaction than their lowerperforming counterparts. Furthermore, post hoc test in Table 6 indicates significant difference among all groups of students according to academic performance. Therefore, teachers need to arrange for manageable classes that will give chances for learners to actively participate in classroom activities, something which has connection to higher academic performance. This is supported by the study of Obi and Kalu (2013) which concluded that classroom interaction patterns significantly enhance the performance and retention of students.

\subsection{There is No Significant Difference in Active Participation By Students Categorized According to Frequency of Engaging in Group Learning Experiences}

The mean score of students' active participation categorized according to frequency of engaging into group learning experiences as shown in Table 7 indicates the mean score of 3.1083 for students who attend very frequently, 3.0588 for those who attend frequently and 2.8958 for those who attend very little. Though this trend suggests that the higher the frequency of attending in group learning activities the greater the student level of active participation in teaching-learning transaction, the Sig. of. 314 in Table 8 reveals that the mean score differences among the three groups are not statistically significant. This does suggest that students tend to be active participants in the teaching-learning experiences regardless of frequency of engaging in group learning experiences. As suggested by Hunkins (2009) and Savage (2009), teachers should allow students to ask questions, to analyze, interpret and predict information, making them the key players in the teaching- learning transaction, having them connect new learning with already existing 
knowledge and actively seek solutions to problems and share ideas of what they constructed themselves.

Table 7. Level of active participation by students according to frequency of participation in group learning experiences

\begin{tabular}{|c|c|c|c|c|c|c|c|c|}
\hline & $\mathrm{N}$ & Mean & Std. Deviation & Std. Error & \multicolumn{2}{|c|}{ 95\% Confidence Interval for Mean } & Minimum & Maximum \\
\cline { 6 - 8 } & & & & & Lower Bound & Upper Bound & & \\
\hline VERY FREQUENTLY & 40 & 3.1083 & .39504 & .06246 & 2.9820 & 3.2347 & 2.00 & 3.67 \\
\hline FREQUENTLY & 17 & 3.0588 & .28224 & .06845 & 2.9137 & 3.2039 & 2.67 & 3.83 \\
\hline LITTLE & 8 & 2.8958 & .29463 & .10417 & 2.6495 & 3.1421 & 2.50 & 3.33 \\
\hline Total & 65 & 3.0692 & .35951 & .04459 & 2.9801 & 3.1583 & 2.00 & 3.83 \\
\hline
\end{tabular}

Table 8. ANOVA of level of active participation by students categorized according to frequency of participation in group learning experiences

\begin{tabular}{|c|c|c|c|c|c|}
\hline & Sum of Squares & df & Mean Square & F & Sig. \\
\hline Between Groups & .304 & 2 & .152 & 1.181 & .314 \\
\hline Within Groups & 7.968 & 62 & .129 & & \\
\hline Total & 8.272 & 64 & & & \\
\hline
\end{tabular}

4.5. There is No Significant Relationship between Students' Academic Performance and the Following Variables: Teaching Modality, Active Participation and Classroom Setup
Table 9 indicates a significant relationship between student academic performance and three important variables namely teaching modalities, student active participation in teaching-learning transaction and classroom setup. This finding has got three important implications in regard to constructivism principles of teaching and learning:

Table 9. Correlations of performance and teaching modality, active participation and classroom setup

\begin{tabular}{|c|c|c|c|c|c|}
\hline & & $\begin{array}{l}\text { What is your performance } \\
\text { average? }\end{array}$ & $\begin{array}{l}\text { Classroom set } \\
\text { up }\end{array}$ & $\begin{array}{c}\text { Teaching } \\
\text { modalities }\end{array}$ & $\begin{array}{c}\text { Active } \\
\text { participation }\end{array}$ \\
\hline \multirow{3}{*}{$\begin{array}{l}\text { Academic } \\
\text { performance }\end{array}$} & $\begin{array}{c}\text { Pearson } \\
\text { Correlation } \\
\end{array}$ & 1 & $-.338 * *$ & $-.290 *$ & $-.333^{* *}$ \\
\hline & Sig. (2-tailed) & & .006 & .019 & .007 \\
\hline & $\mathrm{N}$ & 65 & 65 & 65 & 65 \\
\hline \multirow{3}{*}{ Classroom set up } & $\begin{array}{c}\text { Pearson } \\
\text { Correlation }\end{array}$ & $-.338 * *$ & 1 & $.482^{* *}$ & $.528 * *$ \\
\hline & Sig. (2-tailed) & .006 & & .000 & .000 \\
\hline & $\mathrm{N}$ & 65 & 65 & 65 & 65 \\
\hline \multirow{3}{*}{ Teaching modalities } & $\begin{array}{c}\text { Pearson } \\
\text { Correlation }\end{array}$ & $-.290 *$ & $.482 * *$ & 1 & $.483^{* *}$ \\
\hline & Sig. (2-tailed) & .019 & .000 & & .000 \\
\hline & $\mathrm{N}$ & 65 & 65 & 65 & 65 \\
\hline \multirow{3}{*}{ Active participation } & $\begin{array}{c}\text { Pearson } \\
\text { Correlation } \\
\end{array}$ & $-.333^{* *}$ & $.528 * *$ & $.483^{* *}$ & 1 \\
\hline & Sig. (2-tailed) & .007 & .000 & .000 & \\
\hline & $\mathrm{N}$ & 65 & 65 & 65 & 65 \\
\hline
\end{tabular}

First, teachers should make use of ideal teaching modalities in order to increase the rate of students' academic performance. This includes but not limited to meeting learners at the point of their needs, using strategies that encourage learners to participation in learning, being creative and sensitive in the teachinglearning sessions, using problem-solving and demonstration approaches in teaching, having classroom sessions dominated by a number of activities and using a variety of instructional resources to illustrate abstract ideas.

Secondly, there is need for teachers to create opportunities for learners to actively participate in teaching-learning transaction in order to improve their level of academic performance. This can be accomplished by giving learners time to ask questions and contribute, letting them to be key players in the teaching-learning transactions, allowing them to connect new knowledge with already existing knowledge, guiding them to actively seek solutions to existing problems and letting them discover new information by themselves through a varied range of activities.

Lastly, classroom setup is an important ingredient of constructivism that can influence performance of students, modalities of teaching and the rate of students' active participation. Therefore, school administrations should ensure that classrooms have sufficient space between students; and teachers should make sure that seating arrangement is well organized in such a way that it allows students to interact and teachers to move around during the teaching-learning transaction.

\section{Conclusions and Recommendations}

After analysis of data and discussion, we have come up with the following conclusions and recommendations that have bearing to effective teaching-learning transaction: It has been revealed by students in schools under investigation that their teachers always employ constructivism principles in the teaching-learning transactions by actively engaging learners in classroom sessions.

Students can actively participate in teaching-learning transactions regardless of class size but high performing students tend to engage in active participation more frequently than their lower performing counterparts. Therefore, teachers need to increase teacher-learner and student-student interactive sessions that will give chances for learners to actively participate in classroom activities, 
something which has connection with higher academic performance.

Students tend to be active participants in the teachinglearning experiences regardless of frequency of engaging in group learning experiences. With this regard, teachers are encouraged to use the same effort to motivate those students who engage in group learning experiences and those who do not to increase the rate of active participation in classroom activities. They can accomplish this by allowing students to ask questions, to analyze, interpret and predict information, making them the key players in the teaching- learning transaction, having them connect new learning with already existing knowledge and actively seek solutions to problems and share ideas of what they constructed themselves.

Student academic performance correlates with teaching modalities, student active participation and classroom setup. It is therefore highly recommended that teachers should increase the rate of using learner-centered methodologies of teaching in order to increase the rate of students' academic performance.

Lastly, classroom setup has been found to be an important ingredient of constructivism that can influence performance of students, modalities of teaching and the rate of students' active participation. School administrations are therefore, called upon to ensure that classrooms have sufficient space; teachers are also encouraged to make sure that seating arrangements are well organized to allow students to interact and teachers to move around during the teaching-learning transaction.

Further study can be conducted on teachers' demographic characteristics and application of constructivism theory in teaching-learning transaction.

\section{References}

[1] Al-Rawi, I. Teaching Methodology and its Effect on Quality of Learning. Journal of Education and Practice (Online) www.iiste.org 4, (6). 100-105. 2013.

[2] Bandhana. Designing Instructional Design: Emerging Issues. Journal of Education and Practice (Online) www.iiste.org 1 (3). 18. 2010.

[3] Cohen, L. and Manion, L.Research Methods in Education. Routledge, London, 1962 education. Routledge, London, 1962.

[4] Gagne, R. M., Wager, W.W., Golas, K. C. \& Keller, J. M. Principles of Instructional Design (5th edition). Wadsworth, Californi, 2005.

[5] Ishaq, A and Rani, E. O. Comparative Analysis of the Discussion and Constructivism Methods of Teaching Adult Learners in Adult Education. Journal of Education and Practice (Online) www.iiste.org 2 (4). 6-9. 2011.

[6] Farrant, J. S (1999). Principles and Practice of Education. Singapore: Longman.

[7] Gillies, R. M and Ashman, A. F. Co-Operative Learning: The Social and Intellectual Outcomes of Learning in Groups. (Online Book). www.questia.com Routledge Falmer, London, 2002.
[8] Lingenfelter, J. E. and Lingenfelter, S. G. (2003). Teaching crossculturally: An Incarnational Model for learning and teaching. Michigan: Baker Academic.

[9] Massouleh, N. S and Jooneghani, R. B (2012). Learner Centred Instruction: A Critical Perspective. Journal of Education and Practice (Online) www.iiste.org 3 (6). 50-60. 2012.

[10] Moore, K.D. Effective Instructional Strategies. SAGE, Los Angeles, 2009.

[11] Moyles, J and Hargreaves, L (editors). The Primary Curriculum: Learning from International Perspective (electronic edition). Routledge, London, 2003.

[12] Obi, N. C and Kalu, I (1013). Kitchen Resources Classroom Interaction and Academic Performance and Retention of SS2 Chemistry Students in Thermo chemistry. Journal of Education and Practice (Online) www.iiste.org 4 (8) 169-173. 2013.

[13] Odagboyi, I. A; Sambo, M.H; Musa, A. J. and Onche, E.U (2014). Innovations In Teaching: Between Research And Classroom. Journal of Education and Practice (Online) www.iiste.org 5 (1). 123-127. 2014.

[14] Olukayode, A. S and Tina, S. E. (2013). Effects of Cooperative Learning and Field Trip Strategies on Secondary School Students' Knowledge of and Attitudes to Multicultural Concepts in Social Studies. Journal of Education and Practice (Online) www.iiste.org 4, (22). 35-43. 2013.

[15] Oluoch, E. (2014). Teacher Level of Interaction with Learners Based on Classroom Seating Position. Journal of Education and Practice (Online) www.iiste.org. 5 (17). 114-122. 2014.

[16] Ornstein, A. G and Hunkins, F. P. Curriculum: Foundations, Principles and Issues. Pearson, Boston, 2009.

[17] Reigeluth, C. M. Instructional Design Theories and Models: A New Paradigm of Instructional Theory (Volume 2) (Online Book). Lawrence Erlbaum Associates, Mahwah, N. J, 1999.

[18] Reiser, R. A and Dempsey, J. V (2007). Trends and issues in instructional design and technology $\left(2^{\text {nd }}\right.$ ed.). New Jersey: Pearson Education, Inc.

[19] Savage, T. V. Teaching self-control through management and discipline. Allyn and Bacon, Boston, 1999.

[20] Schunk, D. H. Learning Theories: An Educational Perspective. Pearson, New Jersey, 2004.

[21] Simkins, M., Cole, K., Tavalin F. and Means, B. Increasing student-learning through multimedia projects. ASCD, USA, 2002.

[22] Slavin, Robert E. Educational Psychology: Theory and Practice. Pearson Education, Inc., New Jersey, 2009.

[23] Smaldino, S. E; Lowther, D.L; and Russel, J. D. Instructional Technology and Media for Learning, Pearson Merrill Prentice Hall, New Jersey 2008.

[24] Supriyadi (2013). Developing Teaching Material of Writing Scientific Paper using Constructivism Approach. Journal of Education and Practice (Online) www.iiste.org 4 (24). 34-42. 2013.

[25] Thungu, Wandera, Gachie and Alumande. Mastering PTE Education. Oxford University Press, East Africa LTD Nairobi, 2010.

[26] Tuckman, B. W and Munetti, D. M. Educational Psychology. International Edition. Wadsworth, United States, 2011.

[27] Yemi, T. M and Adeshina, A. N. G. (2013). Factors Influencing Effective Learning of Mathematics at Senior Secondary Schools within Gombe Metropolis, Gombe State Nigeria. Journal of Education and Practice (Online) www.iiste.org. 4 (25). 61-67. 2013.

[28] Zanden, J. W. V. Educational Psychology in Theory and Practice. Random House, Inc, USA, 1980. 